\title{
Influence of Wildland Fire Along a Successional Gradient in Sagebrush Steppe and Western Juniper Woodlands
}

\author{
Eva K. Strand, ${ }^{1}$ Stephen C. Bunting, ${ }^{2}$ and Robert F. Keefe ${ }^{1}$ \\ Authors are ${ }^{1}$ Assistant Professors and ${ }^{2}$ Professor, Department of Forest, Rangeland, and Fire Sciences, University of Idaho, Moscow, ID 83844, USA.
}

\begin{abstract}
Western juniper (Juniperus occidentalis Hook. var. occidentalis) has been expanding into sagebrush (Artemisia L. spp.) steppe over the past $130 \mathrm{yr}$ in Idaho, Oregon, and California. Fuel characteristics and expected fire behavior and effects change as sagebrush steppe transitions into juniper woodlands. Little is currently known about how wildfire influences burn severity and ecosystem response in steppe altered by woodland conversion. In 2007, the Tongue-Crutcher Wildland Fire burned 18890 ha along a successional gradient ranging from sagebrush steppe to mature juniper woodlands, providing a unique opportunity to evaluate the effects of prefire vegetation on burn severity and ecosystem response across spatial scales. Plot-scale burn severity was evaluated with the composite burn index (CBI) in locations where prefire vegetation data were available, and landscapescale burn severity was estimated via remotely sensed indices (differenced normalized burn ratio [dNBR] and relative differenced normalized burn ratio [RdNBR]). Strong positive relationships exist between CBI and remotely sensed burn severity indices in woodlands, whereas the relationships are weaker in steppe vegetation. Woodlands in late structural development phases, and sagebrush patches near developed woodlands, incurred higher burn severity than steppe and young woodlands. The results support the idea that a threshold exists for when juniper-encroached sagebrush steppe becomes difficult to restore. Implications for fire management in sagebrush/juniper ecosystems are discussed.
\end{abstract}

Key Words: burn severity, dNBR, Great Basin, juniper expansion, landscape pattern, RdNBR, remote sensing, succession, vegetation response

\section{INTRODUCTION}

Since Euro-American settlement juniper (Juniperus L. spp.) woodlands have expanded into areas previously covered by grasslands and shrub steppe across the semiarid western United States because of suppression of wildfires, historical excessive livestock grazing, and episodic variation in climate (Burkhardt and Tisdale 1976; Miller and Rose 1995; Miller et al. 2005). Juniper expansion has led to alteration of habitats (Reinkensmeyer et al. 2007), a reduction in plant species diversity (Bunting et al. 1999), increased soil erosion (Pierson et al. 2007), and a loss of land productivity (Bates et al. 2000; Miller et al. 2005). Implementation of prescribed burning programs or allowing wildfires to burn in areas that are becoming occupied by juniper woodlands are means of restoring sagebrush steppe by reducing the juniper expansion (Miller et al. 2005; Bunting et al. 2007; Bates and Svejcar 2009). Changes in vegetation structure and composition that occur during the conversion of sagebrush steppe to juniper woodlands result in changes in fuel loads and expected fire behavior (Yanish 2002; Stebleton and Bunting 2009). Because fire has been effectively reduced in these ecosystems over the past few decades, the opportunity to research the effect of broad-scale high-intensity wildfire on vegetation mortality, composition, and vegetation recovery along the woodland development gradient has been limited.

Research was funded by the Bureau of Land Management, Boise District, Idaho.

Correspondence: Dr Eva Strand, Dept of Forest, Rangeland, and Fire Sciences, PO Box

441135, University of Idaho, Moscow, ID 83844, USA. Email: evas@uidaho.edu

Manuscript received 28 March 2013; manuscript accepted 9 August 2013.

(c) 2013 The Society for Range Management
The potential for remote sensing to increase significantly the amount of information available for decision support in natural resource management has not been fully explored, particularly in shrub steppe and woodland ecosystems. The large extents, and in many cases the inaccessible nature of areas burned in wildland fires, make remote-sensing technology an important tool in natural-resource science and management (Hardy et al. 2001). Remote sensing has been proven suitable for assessing change in vegetation because burned vegetation shows a large reduction in the visible to near-infrared region $(0.4-1.3 \mu \mathrm{m})$ of the electromagnetic reflectance spectrum compared to live vegetation and an increase in the short-wave infrared reflectance $(1.6-2.5 \mu \mathrm{m})$ because of an increase in soil exposure, an increase in charred vegetation, and a decrease in green vegetation (Lentile et al. 2006). Remote-sensing technology has been successfully used in semiarid ecosystems to evaluate burn severity (Diaz-Delgado et al. 2003; Smith et al. 2005) and the identification of areas in need of postfire restoration (RuizGallardo et al. 2004).

The widely used normalized burn ratio (NBR) relies on Landsat TM/ETM bands 4 (near infrared) and band 7 (midinfrared), lower reflectance in the near-infrared region, and higher reflectance in the middle infrared as a consequence of vegetation reduction (Lopez Garcia and Caselles 1991; Key and Benson 2006). The temporal difference between the preand postfire NBR values is referred to as the differenced normalized burn ratio (dNBR; Key and Benson 2006) and has become the primary method for mapping large remote fires (Cocke et al. 2005; Key and Benson 2006). Burned area reflectance classification maps derived from dNBR are readily available to land managers in the United States. This difference 


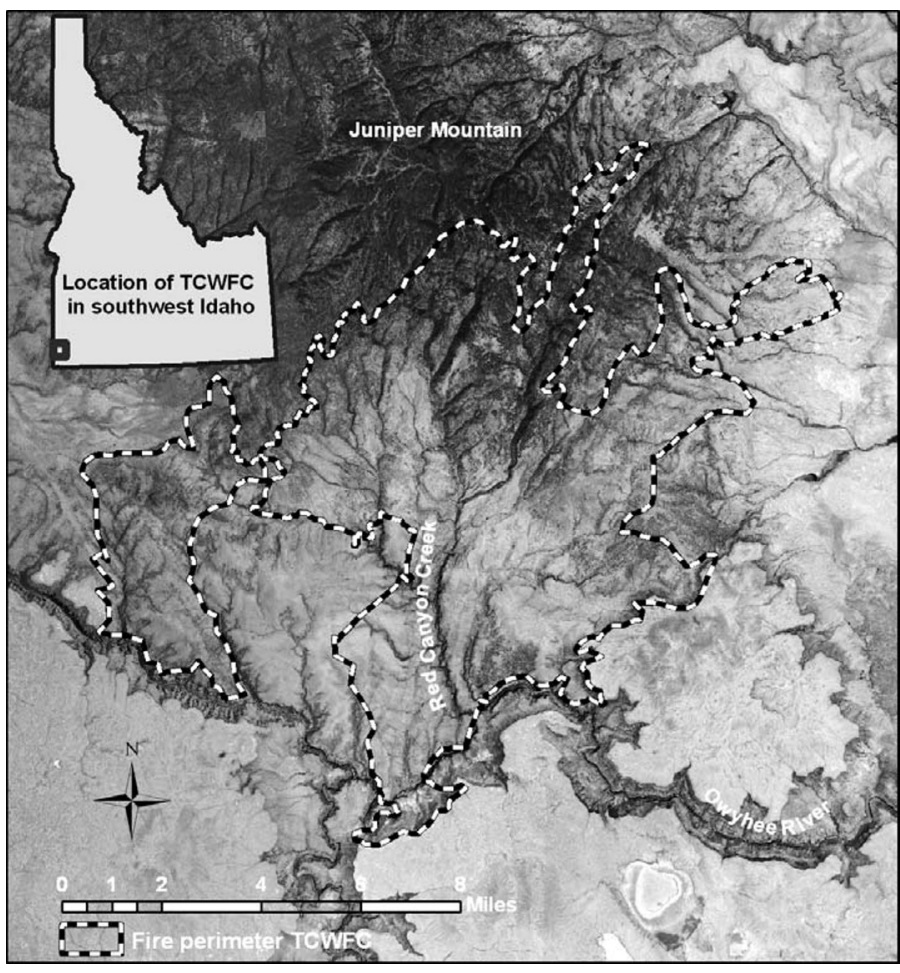

Figure 1. Location of the study area, including the final burn perimeter, for the Tongue-Crutcher Wildland Fire Complex in southwestern Idaho.

index provides separation of burned area from unburned surroundings and a measure of burn severity on prefire vegetation communities (van Wagtendonk et al. 2004; Key and Benson 2006). The relative differenced normalized burn ratio (RdNBR), a variant of the $\mathrm{dNBR}$, was devised to improve performance in open vegetation types by dividing the dNBR by the prefire NBR value (Miller and Thode 2007). RdNBR was designed to measure the amount of postfire vegetation present on the site in relationship to the amount of vegetation present before the fire (Miller and Thode 2007). We recognize that limitations exist in using these remotely sensed indices (dNBR and $\mathrm{RdNBR}$ ) to assess burn severity due to the many dimensions of burn severity, e.g., biomass consumption, soil heating, alteration of soil properties, and plant mortality. However, the dNBR family of indices produce a strong correlation with vegetation mortality (Smith et al. 2007; Lentile et al. 2009) and in the following study we interpret the indices in that context.

Although there are several studies aimed at linking field measurements of fire effects and remotely sensed burn severity in forests (French et al. 2008; Kasischke et al. 2008), there is a lack of evaluation of remote sensing technology for postfire effects assessments in rangelands. The Tongue-Crutcher Wildland Fire Complex (TCWFC), which burned 18890 ha on the Owyhee Plateau in southwestern Idaho in July 2007, presented a unique opportunity to research the effects of prefire vegetation characteristics on postfire burn severity, burn patterns, and postfire vegetation recovery in sagebrush-juniper vegetation. This high-intensity fire burned areas along the steppe/woodland successional gradient including all stages of juniper development, ranging from sagebrush steppe to mature juniper woodlands, including Phase 1, 2, and 3 woodlands as defined by Miller et al. (2005). In Phase 1 of woodland development, juniper trees are present but shrubs and herbaceous vegetation dominate ecological processes such as nutrient and energy cycling. In Phase 2 trees are codominant with the shrubs and herbaceous vegetation, and in Phase 3 the juniper trees dominate the influence over ecological processes on the site. In this research, prefire vegetation composition was available for over 100 sites within the burn perimeter.

The objectives of this research are threefold: 1) to evaluate the linkage between the ground-based CBI and remote estimates of burn severity (dNBR and RdNBR) for sagebrush steppe and juniper woodland vegetation; 2) to evaluate how the magnitude of remotely sensed burn severity is related to the prefire potential vegetation type and vegetation structure at the landscape scale along the sagebrush steppe/woodland successional gradient immediately, 1 , and $2 \mathrm{yr}$ postfire; 3 ) to evaluate the relationship between burn severity and the surrounding landscape pattern of prefire vegetation at distances ranging from 100-300 $\mathrm{m}$. We address three of the future directions for fire-related remote sensing research proposed by Lentile et al. (2006). Specifically we evaluate ecological effects of fire at a landscape level, research the linkage between prefire stand composition and postfire effects, and integrate remote sensing and field assessments.

\section{METHODS}

\section{Study Region}

The Owyhee Plateau covers over 500000 ha in Owyhee County in southwestern Idaho, approximately $135 \mathrm{~km}$ southwest of Boise, Idaho (lat $42^{\circ} 20^{\prime} \mathrm{N}$, long $116^{\circ} 50^{\prime} \mathrm{W}$, Fig. $1)$. The plateau is comprised of three mountain ranges, the Silver City Range to the north, South Mountain in the middle, and Juniper Mountain in the south. These mountain ranges are separated by deep canyons, rocky table lands, and rolling plains, ranging in elevation between 1250 and $2560 \mathrm{~m}$. The average annual precipitation ranges from 30 to $56 \mathrm{~cm}$ (Western Regional Climate Center [WRCC] 2003) in the juniper zone, and occurs primarily in the winter as snow and in early spring in the form of rain. The average temperatures range from $-6.6^{\circ} \mathrm{C}$ in December to $26.7^{\circ} \mathrm{C}$ in July (WRCC 2003). Soils and geology of the area is variable and complex. Juniper Mountain, the area affected by the TCWFC, resulted from basaltic eruption and is composed of large areas of ashflow tuff and ignimbrite (Harkness 1998) and the dominant soil types within the burned area are haplargids at lower elevations, haploxeralfs at intermediate elevation (the majority of the burn), and argixerolls towards the crest of Juniper Mountain.

Prefire vegetation was characterized by sagebrush steppe and western juniper (Juniperus occidentalis Hook. var. occidentalis) woodlands in various stages of development. The dominant sagebrush species are little sagebrush (Artemisia arbuscula Nutt.) on shallow clayey soils and mountain big sagebrush (Artemisia tridentata ssp. vaseyana [Rydb.] Beetle) at higher elevation and on deeper soils. Other shrubs include rabbitbrush (Chrysothamnus Nutt. spp.) and bitterbrush (Purshia tridentata [Pursh] DC.). Common mountain shrub species are curl-leaf mountain mahogany (Cercocarpus 
Table 1. Potential vegetation types (PVT) and structure classes (SS) within the fire perimeter. The codes are used in Figure 3 to describe the structure class.

\begin{tabular}{clcc}
\hline \multicolumn{1}{c}{ PVT } & \multicolumn{1}{c}{ Structure (SS) } & Code & Area (ha) \\
\hline Western juniper/little & Sagebrush steppe open & S1 & 1145 \\
sagebrush (Juoc/Arar) & Sagebrush steppe closed & S2 & 3003 \\
& Woodland-Phase 1 & P1 & 1917 \\
& Woodland-Phase 2 & P2 & 747 \\
& Woodland-Phase 3 & P3 & 774 \\
& Woodland-mature & M & 634 \\
Western juniper/mountain & Sagebrush steppe open & S1 & 2012 \\
big sagebrush (Juoc/Artr) & Sagebrush steppe closed & S2 & 1178 \\
& Woodland-Phase 1 & P1 & 719 \\
& Woodland-Phase 2 & P2 & 865 \\
& Woodland-Phase 3 & P3 & 375 \\
Western juniper/curl-leaf & Woodland-mature & M & 1087 \\
mountain mahogany (Juoc/Cele) & Open shrubland & C1 & 481 \\
Other & Tall multistrata shrubland & C2 & 391 \\
& & & 1283 \\
\hline
\end{tabular}

ledifolius Nutt.), snowbrush ceanothus (Ceanothus velutinus Douglas ex Hook.), mountain snowberry (Symphoricarpos oreophilus A. Gray), bittercherry (Prunus emarginata [Douglas ex Hook.] D. Dietr.), and chokecherry (Prunus virginiana L.). Common grass species are bluebunch wheatgrass (Pseudoroegneria spicata [Pursh] A. Löve), Idaho fescue (Festuca idahoensis Elmer), needlegrass (Achnatherum P. Beauv. spp.), and Sandberg bluegrass (Poa secunda J. Presl). Common perennial forbs include arrowleaf balsamroot (Balsamorhiza sagittata [Pursh] Nutt.), lupine (Lupinus L. spp.), desert parsley (Lomatium Raf. spp.), buckwheat (Eriogonum Michx. spp.), and paintbrush (Castelleja Mutis ex L.f. spp.) and annual forbs such as autumn willow-herb (Epilobium brachycarpum C. Presl), cryptantha (Cryptantha Lehm. ex G. Don spp.), and blue-eyed Mary (Collinsia parviflora Lindl.). Exotic annual grasses such as cheatgrass (Bromus tectorum L.) are present in small amounts throughout the area.

On Juniper Mountain, western juniper is increasing in density or expanding into three different vegetation types, hereafter referred to as the potential vegetation types (PVTs): western juniper/little sagebrush (Juoc/Arar), western juniper/ mountain big sagebrush (Juoc/Artr), and western juniper/curlleaf mountain mahogany (Juoc/Cele) (Bunting et al. 2007). Western juniper is also expanding into quaking aspen (Populus tremuloides Michx.) woodlands (Strand et al. 2009); however, the area of aspen within the burn was only $2 \mathrm{ha}$ and therefore not included in this analysis. The potential vegetation type (PVT) classification was developed as part of the Interior Columbia Basin Ecosystem Management Project midscale analysis (Quigley et al. 1996, US Department of Agriculture [USDA] Forest Service 1996). PVTs represent the species that would grow on a site in the absence of natural or anthropogenic disturbance events. PVTs are further defined as groupings of habitat types that have similar overstory composition, structure, and environmental requirements and are consequently a broader classification than habitat types of the Columbia river basin.

The TCWFC started by lightning in two nearby locations along the Owyhee River south of Juniper Mountain on July 6, following an unusually dry spring in 2007. On 6 July weather stations in Rome, Oregon and Murphy, Idaho report maximum temperatures of over $38^{\circ} \mathrm{C}$, daytime relative humidity below $10 \%$, and variable winds with gusts up to $22 \mathrm{~ms}^{-1}$. By 11 July the fire had burned north towards the foothills of Juniper Mountain through 12000 ha of mostly little and mountain big sagebrush steppe. Over the next few days the high-intensity wildfire burned through a variety of vegetation, including juniper woodlands in mid- to late successional stages with greater fuel loads than the intermingled sagebrush steppe. At times, the fire exhibited extreme fire behavior including crowning, torching, and spotting. Suppression action began around 11 July, dozer lines were completed on the northern edge by 17 July, and the fire was mostly contained by 21 July. Altogether the final fire perimeter encompassed an area of 18890 ha.

\section{Prefire Data and Maps}

Prior to the fire, over 900 vegetation plots had been established across the Owyhee Plateau (Bunting et al. 1999; Yanish 2002; Roth 2004; Strand et al. 2009), where prefire vegetation structure was recorded during the time period 1998-2005; 152 of those plots were located within the fire perimeter. At each location the canopy cover of western juniper, shrubs, perennial grass, annual grass, perennial forbs, and annual forbs within 15-m-radius plots was recorded by ocular estimate in all plots. Intensive sampling was performed in $12 \%$ of the plots to train personnel and to develop a baseline for the ocular estimates. In the intensively sampled plots, shrub cover was estimated via the line-intercept method and herbaceous cover was estimated by placing $2520 \times 50 \mathrm{~cm}$ quadrats along the line-intercept tape and then averaging the canopy cover reading for the entire plot. These field data were used to guide image analysis of Landsat images to produce detailed potential vegetation type (PVT) and vegetation structure maps for 500000 ha of the Owyhee Plateau (Roth 2004), including $90 \%$ of the area that burned in the TCWFC in 2007. The mapped potential vegetation types (Table 1) experiencing juniper encroachment include mountain big sagebrush, little sagebrush, and curl-leaf mountain mahogany. Within the little and mountain big sagebrush PVTs, six vegetation structural stages were mapped (Bunting et al. 2007; Table 1): sagebrush steppe open $(<10 \%$ shrub canopy cover $)$, sagebrush steppe closed ( $\geq 10 \%$ shrub canopy cover), initiation woodland (Phase 1-canopy cover of young, sometimes midage, juniper $<5 \%$ with sagebrush communities intact except directly under trees), young woodland (Phase 2 -canopy cover of young and midaged juniper between 5\% and $15 \%$ with sagebrush and associated species in decline, skeletons often present), young multistory woodland (Phase 3 -canopy cover of young and midaged juniper $>15 \%$, few to no mature trees, sagebrush skeletons numerous in understory), and mature woodland (canopy of mostly mature trees $>15 \%$ cover with sagebrush present only in open areas). The woodland structural stages, Phases 1-3 and mature 
woodland, follow the general classification developed by Miller et al. (2005). Within the fire perimeter, two structural stages of the western juniper/curl-leaf mountain mahogany PVT were present, namely, open (10-67\% canopy cover) and tall multistrata shrubland (>67\% canopy cover) (Table 1 ).

\section{Postfire Field Data Collection}

We used the composite burn index (CBI) method and field forms (Key and Benson 2006, FIREMON) to evaluate burn severity for rating factors and strata on the ground. CBI has been widely used as a field assessment of burn severity in the United States (vanWagtendonk et al. 2004; French et al. 2008; Kasischke et al. 2008), and its use has been recommended in a scientific review by Lentile et al. (2006). Specifically, the CBI protocol records fire effects based on ocular estimates in five vertical strata: 1) surface fuels and soil substrates; 2) herbs, low shrubs, and trees less than $1 \mathrm{~m}$ tall; 3 ) shrubs and trees 1$5 \mathrm{~m}$ tall; 4) intermediate trees; and 5) large trees. We modified the protocol to also specifically consider shrubs $1-2 \mathrm{~m}$ tall in a separate stratum because of their common occurrence in the semiarid shrub/woodland. Variables describing fire effects in each stratum are visually estimated, e.g. fuel consumption, percentage of the foliage that is altered (unburned, scorched, and torched), scorch height, and change in live canopy cover. Each factor is rated on a scale of $0-3$ using specific indicators, where 0 represents unburned areas and 3 represents areas of greatest burn severity. The final CBI score represents the average of the ratings for individual strata. Strata that cannot be scored, for example tree strata in shrublands, are not included in the average score. Altogether, 105 plots previously sampled in 1998-2005 were resampled in 2008, 1 yr after the fire. At each plot (15-m radius) we recorded geographic coordinates at the plot center (GPS $\sim 2-3 \mathrm{~m}$ accuracy), CBI, canopy cover of the six most predominant species, total cover of juniper, tall shrubs $(>3 \mathrm{~m})$, medium shrubs $(1-3 \mathrm{~m})$, perennial grass, perennial forbs, annual grass, annual forb, and the topographic variables slope, aspect, and elevation. CBI was also evaluated postfire at eight additional plots.

\section{Image Processing and Spatial Analysis}

Remote characterization of burn severity was conducted by deriving the widely used dNBR index (Key and Benson 2006) and the RdNBR index (Miller and Thode 2007) from a preand postfire Landsat 5 satellite images with $30-\mathrm{m}$ resolution. Cloud- and smoke-free pre- and postfire Landsat 5 images were selected from the middle of the summer to avoid significant changes in phenology between images from different time periods. Four images were processed-prefire image (21 June 2007), immediate postfire image (1 August 2007), 1 yr postfire (18 July 2008), and 2 yr postfire (21 July 2009). We included a 2 -yr postfire image to evaluate longerterm vegetation response rather than only the immediate fire effects. The images were co-registered within one pixel, and the raw image digital numbers were converted to at-sensor reflectance values (Chander and Markham 2003) with the use of the ENVI image analysis software (ITT Visual Information Solutions 2010) on a Windows XP workstation. Atmospheric correction was not conducted because atmospheric scattering is negligible in the infrared bands (Avery and Berlin 1992).
The spectral burn severity indices were derived from Landsat band $4(0.76-0.90 \mu \mathrm{m})$ and band $7(2.08-2.35 \mu \mathrm{m})$, with the use of grid algebra according to the following equations (Key and Benson 2006; Miller and Thode 2007):

$$
\begin{array}{r}
\mathrm{NBR}=1000(\text { Band } 4-\text { Band } 7) /(\text { Band } 4+\text { Band } 7), \\
\mathrm{dNBR}=\text { NBR prefire }- \text { NBR postfire } \\
\operatorname{RdNBR}=(\text { NBR prefire }- \text { NBR postfire }) \\
/ \sqrt{\mathrm{ABS}([\mathrm{NBR} \text { prefire } / 1000])}
\end{array}
$$

Field reference data were overlain with the burn severity layers and the burn severity index value at each field plot was extracted in a GIS with the point intersect tool in the Hawth's Tools (http://www.spatialecology.com) extension in ArcGIS (ESRI Software 2010). Burn severity index values within PVTs and vegetation structural stages were extracted by overlaying the burn severity index maps from different time periods with the PVT and vegetation structure map developed by Roth (2004) for the Owyhee Plateau. To evaluate whether there is a significant difference in magnitude of burn severity between PVTs and between vegetation structural stages within PVTs (objective 2), approximately 2000 random points were distributed within the fire perimeter in a GIS (ESRI Software 2010), and the burn severity values for each point was extracted with the use of the point intersect tool in Hawth's tools. Only burned pixels within vegetation types were considered, leaving all pixels with an immediate dNBR value $<99$ out of the analysis because those pixels were classified as unburned according to Key and Benson (2006).

In objective 3 we evaluated whether there is a relationship between burn severity and the surrounding landscape pattern of prefire vegetation across spatial scales. We generated 110 random points across the burned area located at least $300 \mathrm{~m}$ apart to avoid spatial overlap between samples. Each pixel of the vegetation structure map was grouped into one of three vegetation classes-sagebrush steppe + Phase 1 woodlands, Phase 2 woodlands, and Phase $3+$ mature juniper woodlands. The remotely sensed indices (dNBR and RdNBR immediately postfire, $1 \mathrm{yr}$ postfire, and $2 \mathrm{yr}$ postfire) were extracted for each random point with the use of the Hawth's point intersect tool. To characterize the vegetation patterns in the immediate vicinity of these points, buffers of 100-, 150-, 225-, and 300-m radii $(3.1,7.1,15.9$, and 28.3-ha neighborhoods) were created around the points with the use of the buffer tool in ArcGIS. The landscape pattern within each buffer was characterized with landscape pattern indices computed in the Fragstats software (McGarigal and Marks 1995). We computed the following landscape pattern indices at the four buffer sizes, in the future referred to as "scales": Area of sagebrush + Phase 1 woodlands, area of Phase $3+$ mature woodlands, and the interspersion and juxtaposition index (IJI), which is a measure of the patch interspersion diversity of edge adjacency of landscape patches. The index ranges from 0 to 100 , and is maximized when each patch type is equally adjacent to all other patch types. These indices provide quantitative information about the composition and spatial arrangement of patches within the 3.1-28.3-ha neighborhoods. 
Table 2. Correlation between composite burn index (CBI) and remotely sensed severity measures for juniper woodlands and sagebrush steppe, immediately after and 1 and 2 yr after the fire. $P=$ probability, $r=$ correlation coefficient, $n=$ number of samples.

\begin{tabular}{lccccccc}
\hline & \multicolumn{3}{c}{ Woodlands } & & \multicolumn{3}{c}{ Sagebrush } \\
\cline { 2 - 3 } Remote sensing measure & $P$ & $r$ & $n$ & & $P$ & $r$ & $n$ \\
\hline dNBR immediate & $<0.0001$ & 0.70 & 80 & & 0.004 & 0.48 & 33 \\
dNBR 1 yr & $<0.0001$ & 0.69 & 80 & & 0.317 & 0.18 & 33 \\
dNBR 2 yr & $<0.0001$ & 0.53 & 80 & 0.984 & 0.00 & 33 \\
RdNBR immediate & $<0.0001$ & 0.65 & 80 & 0.001 & 0.55 & 33 \\
RdNBR 1 yr & $<0.0001$ & 0.66 & 80 & & 0.704 & 0.07 & 33 \\
RdNBR 2 yr & $<0.0001$ & 0.46 & 80 & & 0.174 & 0.24 & 33 \\
\hline
\end{tabular}

\section{Statistical Analysis}

The first objective of this research was to evaluate the linkage between the ground-based CBI and remote estimates of burn severity (dNBR, RdNBR). CBI and the spectral indices (dNBR, $\mathrm{RdNBR}$ ) are continuous variables increasing with burn severity (Key and Benson 2006; Miller and Thode 2007). The significance of the relationship between CBI and spectral indices was quantified with the Pearson's product-moment correlation coefficient $(r)$.

In the second objective we evaluated how the magnitude of remotely sensed burn severity was related to prefire PVT and vegetation structure at the landscape scale along the shrub steppe/woodland successional gradient. The $\mathrm{dNBR}$ and RdNBR indices are continuous variables, which have been shown to increase with increasing burn severity in several ecosystems (Miller and Thode 2007; French et al. 2008; Kasischke et al. 2008). Burn severity values at approximately 2000 random points distributed within burned areas across PVTs and vegetation structural stages were extracted in a GIS (see Image processing and spatial analysis section). The data fulfill the requirements of normality and equal variance necessary for using a parametric ANOVA. A one-way ANOVA $(\alpha=0.05)$ was applied to test for significance in difference in burn severity between the three dominant PVTs (Juoc/Arar, Juoc/Artr, and Juoc/Cele) in the areas that are being encroached by western juniper. One-way ANOVAs were also used to test for significance in remotely sensed burn severity magnitude between structural vegetation stages within each of the three PVTs (see Table 1 for a list of PVTs and structural vegetation stages). We used one-way ANOVAs testing each PVT individually, rather than a multifactor analysis, because comparison of structural stages between PVTs is not of interest for this research question. Statistical tests were performed for burn severity (dNBR and RdNBR) values immediately after the fire, and 1 and $2 \mathrm{yr}$ postfire. Tukey's test for multiple comparisons was used to evaluate which pairs of means differed significantly within PVTs and vegetation structural stages.

In the third objective, we quantified the strength of the relationship between remotely sensed burn severity and vegetation structure within varying sized neighborhoods with Pearson's product-moment correlation coefficient $(r, \alpha=0.05)$.
Table 3. A matrix showing the number of measured field plots that changed from prefire vegetation structural stages to a different structural stage postfire. Some plots remained in the same structural stage because they did not burn although they were located within the fire perimeter. The structural stages are described in Table 1.

\begin{tabular}{lrrrrrrr}
\hline \multicolumn{1}{c}{ Postfire } & S1 & S2 & P1 & P2 & P3 & M & Total prefire \\
\hline Prefire & 0 & 0 & 0 & 0 & 0 & 0 & 0 \\
S1 & 6 & 14 & 0 & 0 & 0 & 0 & 20 \\
S2 & 8 & 1 & 4 & 0 & 0 & 0 & 13 \\
P1 & 5 & 0 & 0 & 0 & 0 & 0 & 5 \\
P2 & 16 & 1 & 0 & 1 & 13 & 0 & 31 \\
P3 & 32 & 0 & 0 & 2 & 0 & 2 & 36 \\
M & 67 & 16 & 4 & 3 & 13 & 2 & 105 \\
Total postfire & The postfire sites classified as S1 were most commonly composed of sparse annual or \\
perennial herbaceous vegetation with no shrubs present.
\end{tabular}

We used the SYSTAT version 10 software from SPSS for all statistical analyses.

\section{RESULTS}

Correlation Between Field and Remotely Sensed Burn Severity The correlation between CBI and the two remotely sensed burn severity indices was significant $(P<0.001)$ immediately after the fire in juniper woodlands, $r=0.70$ for $\mathrm{dNBR}$ and $r=0.65$ for RdNBR (Table 2). The strength of the correlation remained largely unchanged $1 \mathrm{yr}$ after the fire, $r=0.69$ for $\mathrm{dNBR}$ and $r=0.66$ for RdNBR, and decreased two years after the fire, $r=0.53$ and 0.46 , for dNBR and RdNBR, respectively. For sagebrush shrublands, the correlation between CBI measures and remotely sensed severity measures was only significant immediately after the fire, $r=0.48$ for $\mathrm{dNBR}$ and $r=0.55$ for RdNBR (Table 2).

\section{Burn Severity in PVTs and Vegetation Structural Stages}

Change in vegetation structural stage occurred from pre- to postfire at the 105 locations where we had prefire data (Table $3)$. Approximately two-thirds of the sites where prefire vegetation data existed were converted to a sparsely vegetated herbaceous stage, and the remaining third of the sites either burned lightly or did not burn and therefore remained in the same structural stage as prefire. For example, field data were collected at 31 locations in the P3 structural stage. Of those 31 locations, 16 were classified in the $\mathrm{S} 1$ structural stage postfire, one plot was classified as S2, one plot was classified as P2, and 13 plots remained in P3 (unburned but within the fire perimeter).

We used analysis of variance (ANOVA) to test for differences in burn severity among the three PVTs; Juoc/Arar, Juoc/Artr, and Juoc/Cele. Burn severity differed across the three PVTs for dNBR and RdNBR for all three time periods tested (Table 4, Fig. 2). The ANOVA model above was fitted separately for each of the three periods. Means and 95\% confidence intervals for each PVT resulting from Tukey's multiple comparison test are not reported numerically, but are 
Table 4. Results from one-way ANOVA testing for a difference in burn severity index (differenced normalized burn ratio [dNBR] and relative differenced normalized burn ratio [RdNBR]) for the three potential vegetation types (PVTs)—Juoc/Arar, Juoc/Artr, and Juoc/Cele for three time periods.

\begin{tabular}{|c|c|c|c|c|c|c|c|c|c|c|}
\hline \multirow[b]{2}{*}{ Time period } & \multirow[b]{2}{*}{ Source } & \multirow[b]{2}{*}{$d f$} & \multicolumn{4}{|c|}{$\mathrm{dNBR}$} & \multicolumn{4}{|c|}{ RdNBR } \\
\hline & & & Sum of squares & Mean square & $F$ & $P$ & Sum of squares & Mean square & $F$ & $P$ \\
\hline Immediate & PVT & 2 & 3348438 & 1674219 & 159.6 & $<0.001$ & 35942400 & 17971200 & 36.7 & $<0.001$ \\
\hline Immediate & Error & 2095 & 21983600 & 10493 & & & 1027060000 & 490246 & & \\
\hline Immediate & Total & 2097 & 25332038 & & & & 1063002400 & & & \\
\hline 1 yr post & PVT & 2 & 4586584 & 2293292 & 180.8 & $<0.001$ & 48374400 & 24187200 & 95.1 & $<0.001$ \\
\hline $1 \mathrm{yr}$ post & Error & 2095 & 26573100 & 12684 & & & 532651000 & 254249 & & \\
\hline 1 yr post & Total & 2097 & 31159684 & & & & 581025400 & & & \\
\hline $2 \mathrm{yr}$ post & PVT & 2 & 923655 & 461827 & 86.9 & $<0.001$ & 8083620 & 4041810 & 37.2 & $<0.001$ \\
\hline $2 \mathrm{yr}$ post & Error & 2095 & 11128400 & 5312 & & & 227444000 & 108565 & & \\
\hline 2 yr post & Total & 2097 & 12052055 & & & & 235527620 & & & \\
\hline
\end{tabular}

shown in Figure 2. Burn severity is different between each PVT at all time periods for both spectral indices except for the difference between the Juoc/Artr and Juoc/Cele PVTs immediately after the fire with the use of the RdNBR burn severity index.

We also used ANOVA to test for differences in burn severity (dNBR and RdNBR) among vegetation structural stages within PVTs (Juoc/Arar, Juoc/Artr, and Juoc/Cele; Table 1) for the time periods immediately, $1 \mathrm{yr}$, and $2 \mathrm{yr}$ after the fire. It is important to note that our interpretation of the results is based on oneway ANOVAs testing each PVT and time period individually, rather than a multifactor analysis. The one-way analysis is consistent with our hypotheses of interest and the results and interpretation we are reporting. Means and $95 \%$ confidence intervals for each vegetation structural stage resulting from Tukey's multiple comparison tests are not reported numerically but are shown in Figure 3 for dNBR and RdNBR, immediately as well as 1 and $2 \mathrm{yr}$ after the fire. Within the Juoc/Arar PVT the dNBR burn severity was different for all stages of juniper woodland development (P1, P2, P3, and M) with increasing severity in more developed phases. There was, however, no significant difference in dNBR burn severity between the two sagebrush stages and woodland Phase 1. Within the Juoc/Artr PVT the dNBR burn severity was significantly lower for the early successional stages (S1, S2, P1, and P2) compared to the later successional stages ( $\mathrm{P} 3$ and $\mathrm{M})$. There was a significant difference in dNBR burn severity between the two structural stages within the Juoc/Cele PVT (C1 and C2). The dNBR index decreased from 300 to 350 immediately after the fire to 75 to $1002 \mathrm{yr}$ after the fire (Fig. 3).

We observed differences in the RdNBR burn severity index between early (S1, S2, P1) and late (P2, P3, M) successional stages for the Juoc/Arar PVT (Fig. 3). The RdNBR was variable immediately after the fire for the Juoc/Artr PVT, but exhibited a constant increase in burn severity going from early to late successional stages 1 and $2 \mathrm{yr}$ after the fire. There was no
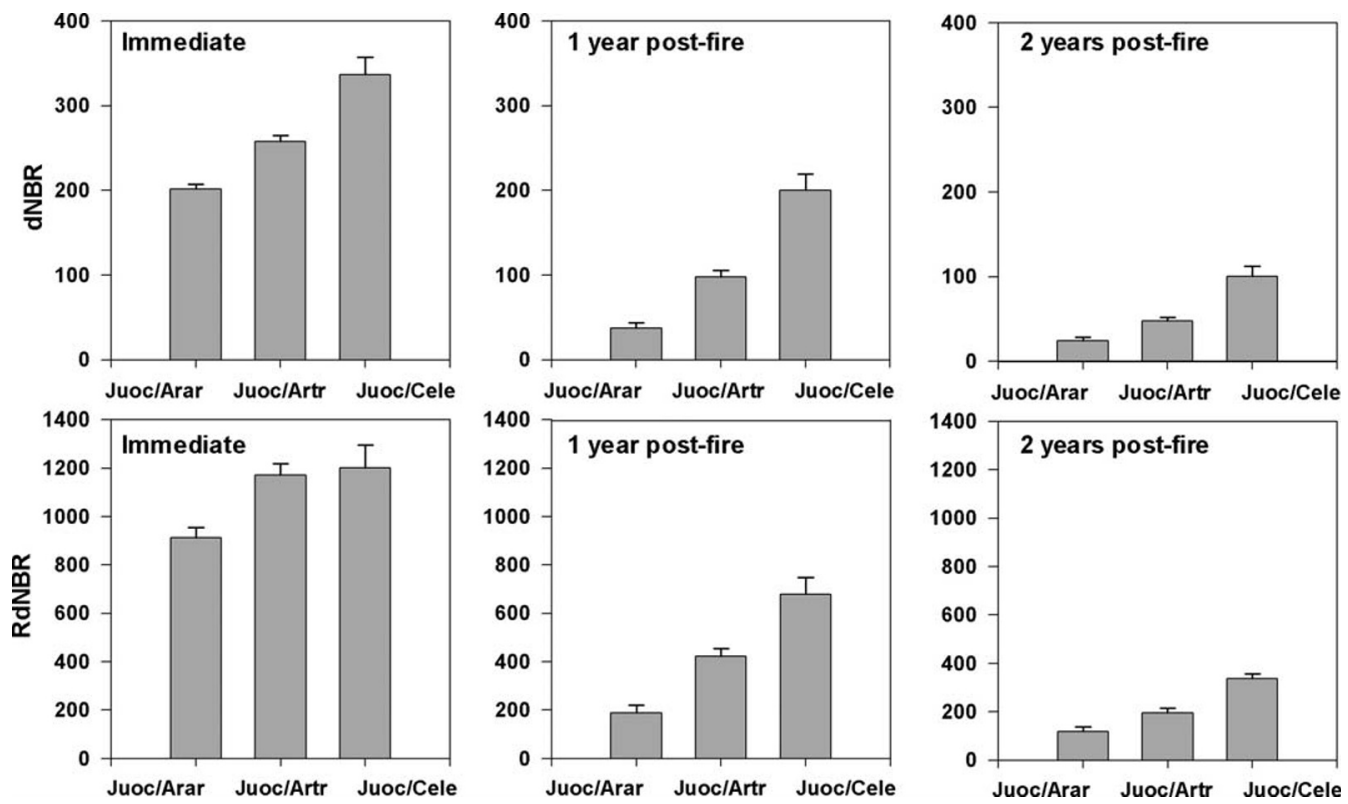

Figure 2. Differences in burn severity between potential vegetation types (PVTs): immediately, 1 yr, and 2 yr postfire. Burn severity is estimated with two remote sensing indices (differenced normalized burn ratio [dNBR] and relative differenced normalized burn ratio [RdNBR]). Burn severity is significantly different between all PVTs at all time periods for both spectral indices except for the difference between the Juoc/Artr and Juoc/Cele PVTs immediately after the fire with the use of the RdNBR index. The error bars indicate the $95 \%$ confidence intervals. 

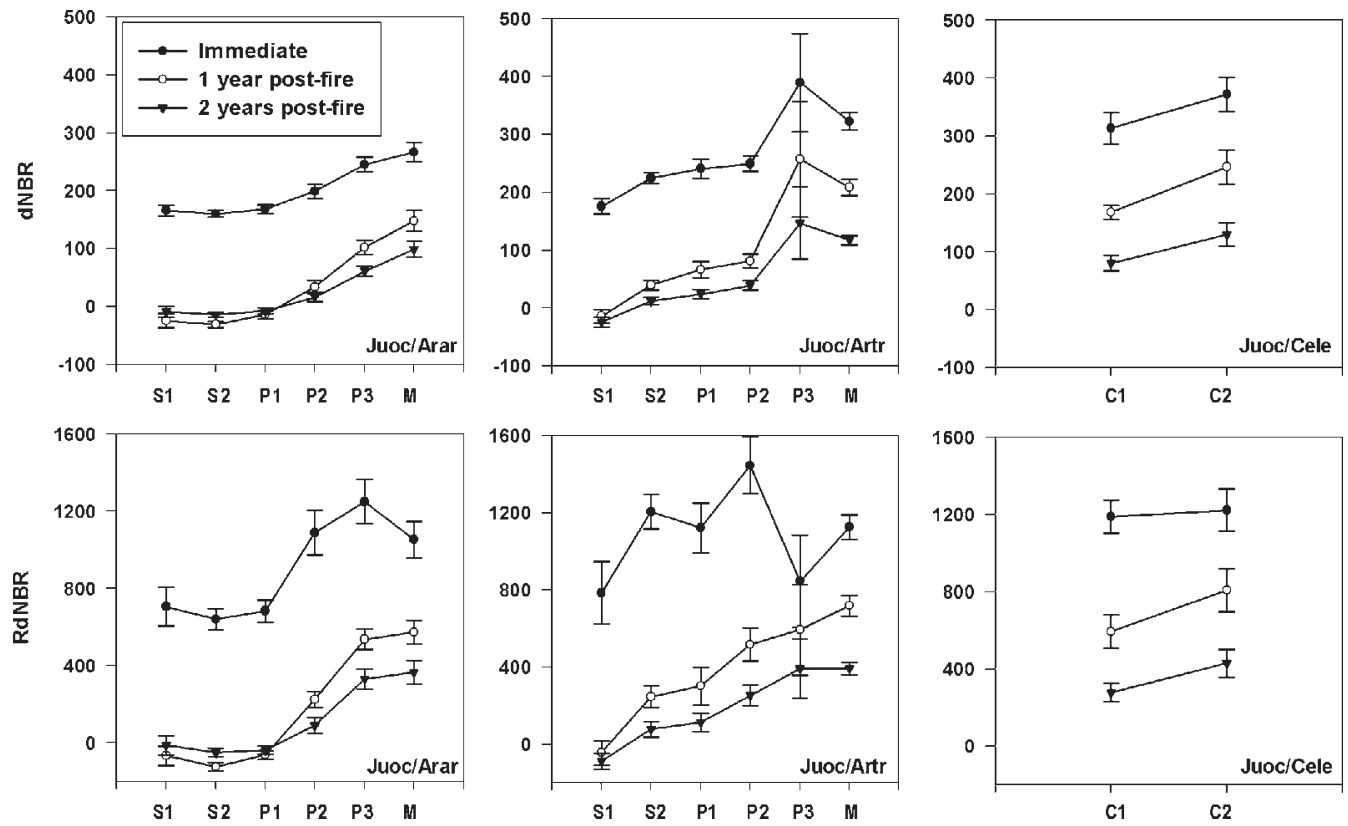

Figure 3. Difference in remotely sensed burn severity (differenced normalized burn ratio [dNBR] and relative differenced normalized burn ratio [RdNBR]) between vegetation structural stages for three potential vegetation types (PVTs) immediately, $1 \mathrm{yr}$, and 2 yr postfire. The error bars indicate the 95\% confidence intervals.

significant difference in RdNBR between the stages C1 and C2. In agreement with the $\mathrm{dNBR}$ index, the RdNBR index indicated that the sagebrush steppe stages for the Juoc/Arar and Juoc/Artr PVTs and P1 for the Juoc/Arar PVT had returned to prefire values already $1 \mathrm{yr}$ after the fire. The more developed woodlands had not returned to prefire NBR values $2 \mathrm{yr}$ after the fire; in fact, the RdNBR index 2 yr after the fire was still approximately 400 for both the Juoc/Arar and the Juoc/Artr PVTs (Fig. 3). Photographs of structural vegetation stages preand postfire are provided in Figure 4.

\section{Vegetation Composition and Spatial Arrangement}

Results from the statistical analysis of the effects of composition and spatial arrangement in prefire vegetation structure on remotely sensed burn severity across scales are summarized in Figure 5. Burn severity (dNBR and RdNBR) in sagebrush steppe (Figs. 5a-5c) was significantly and negatively correlated $(r=-0.37-[-0.74])$ with the area of sagebrush steppe + Phase 1 woodlands at scales ranging from 100-300 m (Fig. 5a); i.e., the more sagebrush steppe/Phase 1 there was within the neighborhood the lower the burn severity in the neighborhood center. The correlation was generally stronger at $300-\mathrm{m}$ scale compared to 100-m scale, and the correlation was stronger at 1 yr postfire compared to immediately after or $2 \mathrm{yr}$ after the fire (Fig. 5a). When the area of Phase 3 and mature juniper woodland increased within the neighborhood the burn severity for the sagebrush center pixel increased for all burn-severity measures and time periods, as indicated by positive correlation coefficients (Fig. 5b). The correlation coefficient generally increased with larger neighborhoods, and the correlation was stronger 1 and 2 yr postfire compared to directly after the fire. Spatial arrangement, here represented by the interspersion and juxtaposition index, exhibited a positive correlation with burn severity, increasing at broader spatial scales (Fig. 5c). In general, the relationships between burn severity and vegetation composition and spatial arrangement were weaker when burn severity was estimated immediately after the fire and became stronger 1 and 2 yr postfire.

Burn severity in Phase 3 and mature woodlands was negatively correlated with the amount of sagebrush within the neighborhood (Fig. 5d) and positively correlated with the amount of Phase 3 and mature woodlands within the neighborhood (Fig. 5e); i.e., the center pixel of Phase 3 juniper experienced higher burn severity when the amount of late successional juniper in the neighborhood was higher. These relationships were statistically significant $(\alpha=0.05)$ for the dNBR burn severity estimate but were not significant when using the RdNBR burn severity index. The spatial arrangement and distribution of vegetation within 100-300-m neighborhoods, IJI (Fig. 5f), did not affect the burn severity in late successional woodlands under intense wildfire conditions.

\section{DISCUSSION}

\section{Remote Sensing of Burn Severity}

In agreement with other researchers (Epting et al. 2005; Hoy et al. 2008) and summarized in the review by French et al. (2008), we found differences in the correlation between CBI and remotely sensed burn severity indices (dNBR and RdNBR) for different cover types (juniper woodlands and sagebrush steppe in this study, Table 2). We found stronger correlations between burn-severity indices and CBI in juniper woodlands compared to sagebrush steppe and conclude that the CBI, dNBR, and RdNBR are accurate indicators of burn severity in juniper woodlands whereas they are less informative in sagebrush steppe. One year postfire the correlation between CBI and remotely sensed burn severity indices were no longer significant 

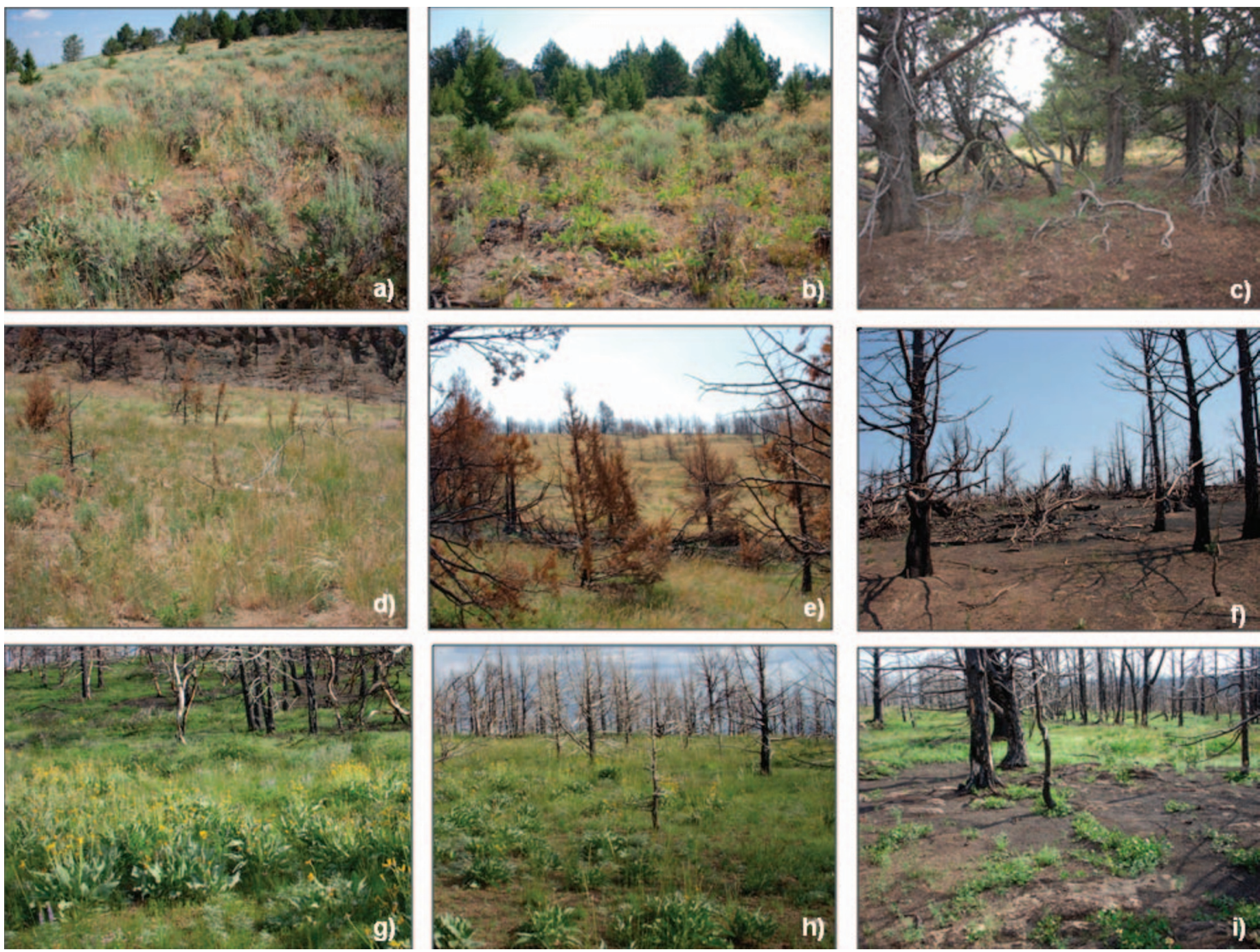

Figure 4. Photographs of a, preburn mountain big sagebrush steppe; $\mathbf{b}$, preburn Phase 2 woodlands; $\mathbf{c}$, preburn Phase 3 woodlands; $\mathbf{d}$, mountain big sagebrush steppe 1 yr postfire; e, Phase 2 woodlands 1 yr postfire; $\mathbf{f}$, Phase 3 woodlands 1 yr postfire; $\mathbf{g}$, mountain big sagebrush steppe 2 yr postfire; $\mathbf{h}$, Phase 2 woodlands 2 yr postfire; i, Phase 3 woodlands 2 yr postfire. The photographs are not taken in the exact same location but in the same potential vegetation type and structural stage.

in sagebrush steppe vegetation, and the vegetation was exhibiting reflectance values that were not significantly different from prefire vegetation values. It should be recognized that this may not mean that the species composition is similar prefire and $1 \mathrm{yr}$ postfire in sagebrush steppe, rather that the reflectance received by the satellite sensor is approaching prefire conditions already $1 \mathrm{yr}$ after fire in this particular area and fire intensity.

The correlations between $\mathrm{dNBR}$ and $\mathrm{CBI}$ were slightly stronger than those between RdNBR and CBI for woodlands, whereas the opposite was true for sagebrush steppe. When comparing the results from dNBR and RdNBR it is important to recall the original development of these indices and the goal for the analysis. The difference in pre- and postfire reflectance in the near-infrared and the short-wave infrared bands are used to derive dNBR. Remotely sensed reflectance in the red and near-infrared bands are closely related to the amount of green vegetation within an image pixel and are strongly related to net primary productivity (Gamon et al. 1995; Wang et al. 2005). In the derivation of RdNBR the change in NBR is divided by the prefire NBR, adjusting for the fact that some pixels do not contain as much green vegetation initially. A pixel with little green vegetation prefire would appear to have a lower dNBR index value than a pixel containing a large amount of green vegetation. RdNBR adjusts for this difference by dividing dNBR by the prefire value. As such, dNBR would be the preferred index when it is important to determine the absolute change in green vegetation during the fire, and RdNBR would be preferred when it is important to know what proportion of the prefire vegetation was removed in the fire.

\section{Burn Severity and Vegetation Response in Sagebrush Steppe and Woodlands}

The common remotely sensed burn severity index dNBR was originally developed in temperate coniferous forests (FIREMON, Key and Benson 2006), but is currently being widely used to map fire and burn severity in other ecosystems including shrub steppe and woodlands. Before initiating a 
Sagebrush
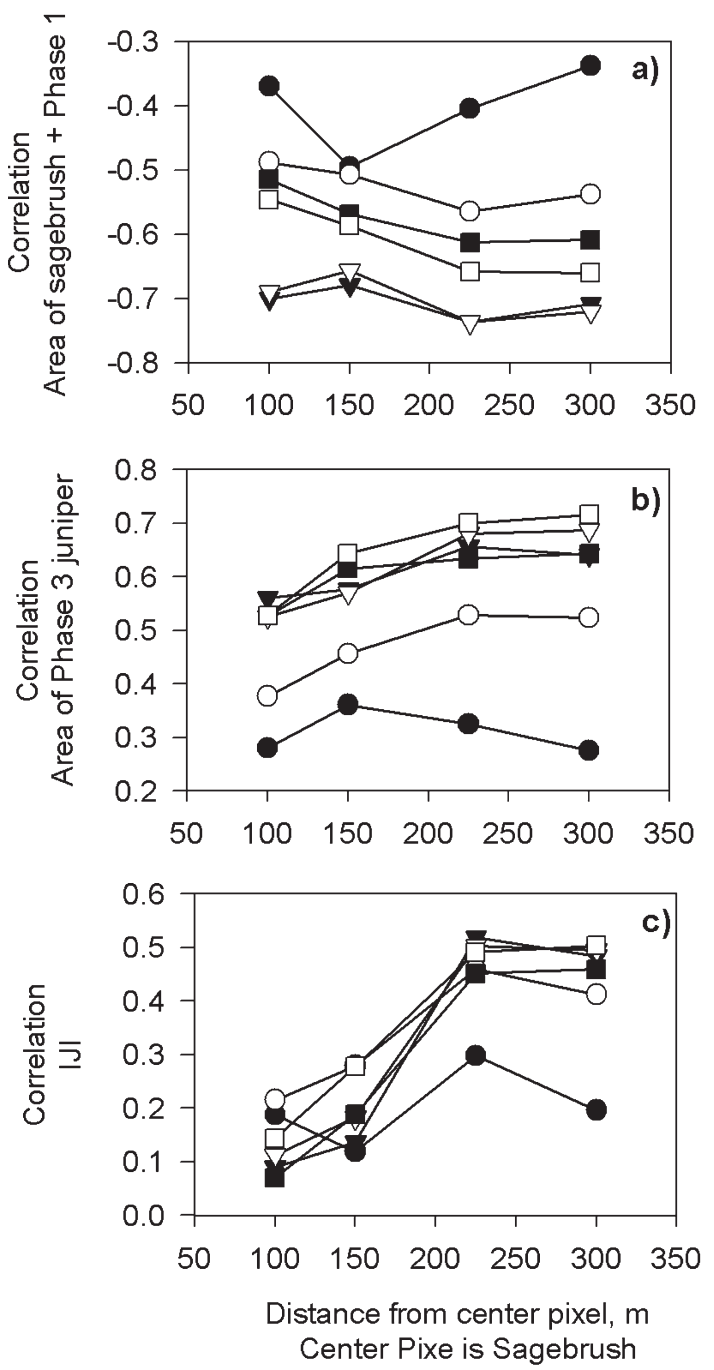

Juniper Phase 3
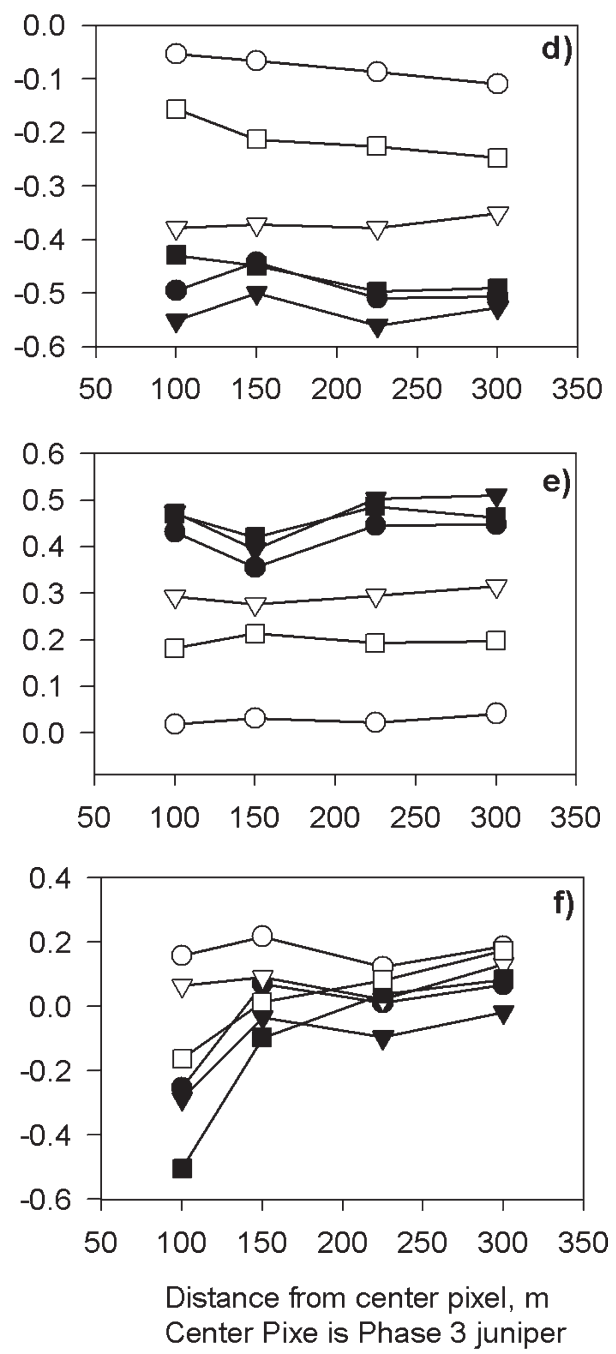

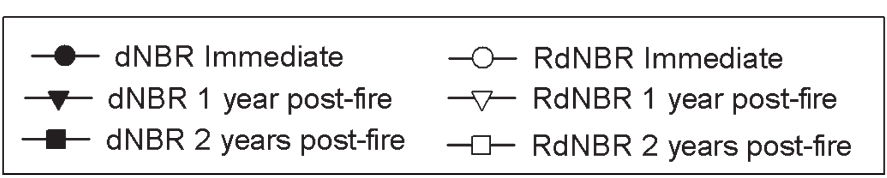

Figure 5. Correlation between burn severity of the center pixel of a circular neighborhood and landscape metrics computed within the circular neighborhood where the center pixel is sagebrush (left column) or western juniper woodlands in Phase 3 (right column). Correlations are computed for the remotely sensed burn severity indices differenced normalized burn ratio (dNBR) and relative differenced normalized burn ratio (RdNBR) immediately after the fire, $1 \mathrm{yr}$, and $2 \mathrm{yr}$ postfire. Correlations are significant $(\alpha=0.05)$ except for RdNBR in $\mathrm{d}$ and $\mathrm{e}$ and for the interspersion and juxtaposition index.

discussion of whether Landsat-derived burn severity indices provide useful information in rangelands, the potential differences in the meaning of burn severity and ecosystem response in forests and sagebrush steppe are discussed.

Burn severity is defined as the magnitude or degree of ecological change or removal of organic matter caused by fire and ecosystem response is related to vegetation mortality and subsequent recovery, and postfire soil effects such as erosion (Keeley 2009). Remotely sensed severity indices are best suited to detect removal of aboveground green vegetation from pre- to postfire conditions and correlates with vegetation mortality (Smith et al. 2007; Lentile et al. 2009). In forests, a high burn severity indicates complete or near-complete removal of the tree canopy, whereas understory burns are considered lowseverity fires. In sagebrush steppe a fire of any intensity will consume a large portion of the aboveground shrub and herbaceous vegetation, unless the fire is patchy and leaves unburned areas interspersed within the fire perimeter. Mountain big sagebrush, for example, is highly susceptible to fire, and plants are readily killed even by low-intensity fires (Neuenschwander 1980; Blaisdell et al. 1982; Bunting et al. 1987). Fire generally consumes the aboveground portion of perennial grasses, but the mortality varies by grass species. Season of burning is important and higher plant mortality has been observed in spring burns, whereas little to no damage is observed if the fire occurs when the plant is dormant in the fall 
(McShane and Sauer 1985; Britton et al. 1990; Sapsis 1990). Range et al. (1982) observed that bluebunch wheatgrass plants killed by fire were commonly located in deep litter or high shrub cover, which can be expected to increase the duration and temperature of the fire.

Ecosystem response and the response of individual plants to fire are highly variable and depend on fire characteristics, season of burn, ecological condition, and pre- and postfire management (Agee 1996). After a fire, rapid tiller development occurs in surviving perennial grass plants (Robberecht and Defosse 1995 ) and new plants may re-establish from seed, if temperatures during the fire were low enough to allow for seed survival. Postfire recovery of bluebunch wheatgrass generally occurs within 1-3 yr (Bunting et al. 1998). For sagebrush plants, regeneration occurs from residual seed in the soil or from migrating seed from nearby unburned plants and regeneration rates can be highly variable (Blaisdell 1953; Ziegenhagen and Miller 2009). Resprouting after fire has not been observed in mountain big sagebrush (Blaisdell 1953). Seedling growth depends on site conditions but reproductive maturity can be reached as early as 3-5 yr after a fire (Bunting et al. 1987). The species composition is therefore often dominated by grasses and forbs the first few years following a fire. Unless exotic plants are affecting succession, the sagebrush steppe community eventually returns to the prefire vegetation composition (Blaisdell et al. 1982; Akinsoji 1988; Bunting 1990). Over time, mountain big sagebrush can be expected to return to preburn density and cover after 15-20 yr, although establishment may proceed more slowly after a highintensity burn (Bunting et al. 1987). Rabbitbrush is commonly top killed in a fire, but may resprout vigorously (Young 1983), whereas bitterbrush is considered a weak resprouter and may sprout after a low-severity fire (Blaisdell and Mueggler 1956).

Considering these differences in recovery rates between sagebrush and perennial grasses, the remotely estimated severity after the fire will likely be highly dependent on the proportions of sagebrush and perennial grass cover on the site prefire. Because total plant cover is lower in sagebrush steppe than in woodlands or forests, the remotely sensed burn severity in sagebrush steppe is generally classified as low to moderate. The extended burn severity assessment $1 \mathrm{yr}$ postfire may, as in this study, show that the sagebrush steppe has returned to prefire reflectance values, even though sagebrush plants are not present. If sagebrush is considered an important part of the ecosystem, one could argue that the burn severity is high for sagebrush plants, and low, moderate, or high for perennial grasses, depending on the degree of perennial grass plant mortality.

Keeley (2009) points out that ecosystem response is of greater interest to resource managers than burn severity. A few important questions relating to long-term ecosystem response in sagebrush steppe and the need for postfire management are as follows: 1) To what degree did the fire cause mortality of perennial grasses, i.e., kill the plants rather than simply remove the aboveground biomass? 2) Was the seed bank affected by the fire? 3) Is there a nearby seed source for sagebrush and other native plants? 4) Are there invasive/exotic species nearby or in the seed bank that may alter the species composition after the fire? These considerations are naturally not accounted for in current burn severity estimates, e.g., CBI, and call for additional field procedures that are specific to assess the expected ecosystem response in sagebrush steppe and other rangeland ecosystems.

We show that woodland vegetation that incurred higher dNBR values immediately after fire, i.e., the later stages of juniper development, was slower to return to prefire dNBR values, indicating that the initial remote estimate of burn severity was a reasonable indicator of expected ecosystem response 1-2 yr postfire in woodlands (Fig. 3). RdNBR, on the other hand, was more variable immediately after the fire, but became similar to the patterns expressed with dNBR 1-2 yr after the fire. We conclude that in juniper woodlands, the immediate dNBR is a better estimator of ecosystem response than the immediate RdNBR. This is important to know because at the time when postfire management decisions must be made, the extended assessment is not yet available, and many decisions are made based on the immediate remote sensing burn severity assessment, also known as Burned Area Reflectance Classification (BARC) maps.

\section{RECOMMENDATIONS FOR SAGEBRSUH STEPPE RESTORATION}

Landscape spatial analysis indicated that there were significant differences in burn severity between the three evaluated potential vegetation types. Not surprisingly, the PVT with the lower fuel loads (Juoc/Arar) burns at lower severity than Juoc/Artr or Juoc/ Cele. See Stebleton and Bunting (2009) for fuel composition in these systems. In addition, early structural vegetation stages, sagebrush steppe, and woodlands in development Phase 1, incurred significantly lower burn severity than woodlands in development Phase 2, 3, or mature, under intense wildfire conditions. Areas that burned later in succession, e.g., development Phase 3 or mature, burned more intensely and will require longer time to return to prefire spectral reflectance. For the Juoc/ Artr PVT in particular there was a drastic increase in burn severity between stands that burned in woodland development Phase 3 compared to earlier phases. Miller et al. (2005) suggested that most abiotic and biotic thresholds for when woodlands may no longer return to sagebrush steppe vegetation after a disturbance occur between Phase 2 and 3 of woodland development. The results presented here provide quantitative evidence that burn severity is significantly higher and the time to return to prefire spectral reflectance values is longer in woodland development Phase 3 or older compared to earlier phases. Important mechanisms contributing to this threshold are likely the increase in coarse woody fuels leading to more intense fires when the area finally burns, accumulation of litter and duff under juniper plants that allow for severe burns and increased mortality of perennial vegetation, the loss of sagebrush and sagebrush seed sources, and decreased cover of many perennial plants in developed woodlands. We observed that the change in species and canopy cover of perennial grasses and forbs was small after a fire in sagebrush steppe vegetation and woodland development Phase 1, although the difference in species composition and canopy cover increased as woodlands developed into Phase 2, 3, or mature woodlands. Postfire vegetation assessments indicated that snowbrush ceanothus was common in areas that were in Phase 3 or mature woodland development before the fire. One and $2 \mathrm{yr}$ after the fire snowbrush was present 
in small amounts; however, this woody plant may quickly become the dominant vegetation in these stands, unless it is consumed by wildlife. Snowbrush ceanothus seeds can persist in the soil for over $200 \mathrm{yr}$ (Gratkowski 1962) and require heat from fire to stimulate germination and establishment (Gratkowski 1962; Conrad et al. 1985). Hence, even though there is no or limited amounts of snowbrush ceanothus on a site before a fire, the seed bank may contain a snowbrush seed source, which may alter successional pathways away from sagebrush steppe vegetation on mesic sites.

Prescribed burn programs and wildland fire use are means of restoring sagebrush steppe and control woodland development. Fire behavior modeling using custom fuel models for sagebrush steppe and the developmental phases of juniper woodlands has shown that Phase 3 and mature woodlands exhibit slower fire spread compared to earlier developmental stages under prescribed burning conditions because of lower loadings of fine surface fuels (Yanish 2002). During surface fires these later developmental stages therefore tend to influence the burn pattern across the landscape strongly (Roth et al. 2011). Under intense wildfire conditions such as those observed during the TCWFC, the later development phases exhibit fire behavior such as torching, crowning, and spotting, resulting in high burn severity, vegetation mortality, and slower ecosystem response. These results reiterate suggestions from previous research (Miller et al. 2005; Bates and Svejcar 2009) that it is desirable to implement prescribed burns or wildland fire use in Phase 1 or 2 woodlands when the objective is to restore sagebrush steppe habitats. In woodlands that have advanced to development Phase 3, burning may result in a failure to meet this management objective.

In objective 3 we assessed whether the prefire vegetation structure within neighborhoods ranging from 100 to $300 \mathrm{~m}$ around an area influences the remotely sensed burn severity in the center of that area. Our results show that under intense wildfire conditions the prefire vegetation structure affects the burn severity in sagebrush steppe such that if a sagebrush steppe pixel is surrounded by sagebrush steppe the center pixel incurs significantly lower burn severity than if the pixel is surrounded by Phase 2, 3, or mature woodlands. Intense fire resulting from burning the greater fuel loads in more developed woodlands releases heat that apparently affects nearby sagebrush patches. Similarly, the burn severity in Phase 3 and mature woodlands is lower when there is more sagebrush steppe or Phase 1 woodlands within the neighborhood; however, the results were only significant if the burn severity was estimated with the dNBR rather than the RdNBR burn-severity index. Potentially, a crown fire may be less likely to burn across a Phase 3 stand if it is surrounded by sagebrush, indicating that these older stands may not be ignited by surface fires but rather via fire in the crowns or spotting. The effect of spatial arrangement on burn severity increased as the neighborhood size increased from 100 to $300 \mathrm{~m}$, indicating that the presence and arrangement of woodland vegetation influences burn severity in sagebrush steppe at distances $300 \mathrm{~m}$ away.

\section{MANAGEMENT IMPLICATIONS}

Commonly used remotely sensed burn-severity indices (dNBR, RdNBR) are useful in assessing burn severity along the sagebrush steppe/juniper woodland gradient. Correlations to ground measurements of burn severity $(\mathrm{CBI})$ in these rangelands are significant and stronger in the woodlands than in the sagebrush steppe. Our research provides quantitative evidence that after an intense wildfire, the burn severity increases along the woodland development gradient. The ecosystem response, estimated with dNBR 1 or 2 yr postfire, is faster for early successional stages compared to the developed woodlands. This research supports previous suggestions (Miller et al. 2005) that there is likely a disturbance-response threshold between Phase 2 and Phase 3 of woodland development after which our ability to predict the postdisturbance vegetation community greatly decreases. Transitions to snowbrush ceanothus shrublands may occur when fires burn under intense conditions in woodlands. Our results suggest that in high-intensity wildfires with extreme fire behavior, burn severity not only increases as woodlands approach late developmental stages, but that the burn severity in nearby sagebrush steppe or Phase 1 woodland patches also increase significantly when woodlands in late development are located within $300 \mathrm{~m}$.

\section{ACKNOWLEDGMENTS}

We would like to acknowledge the Bureau of Land Management, Boise District, Idaho for partial funding for this project. We thank students and assistants that helped with literature research, field data collection, and data management. This publication is issued as Contribution No. 1074 of the Idaho Forest, Wildlife and Range Experiment Station, University of Idaho, Moscow, ID, USA.

\section{LITERATURE CITED}

AgEE, J. K. 1996. Fire in the Blue Mountains: a history, ecology, and research agenda. In: R. G. Jaindl and T. M. Quigley [EDS.]. Search for a solution: sustaining the land, people and economy of the Blue Mountains. Washington, DC, USA: American Forests. p. 119-145.

AkINSOJI, A. 1988. Postfire vegetation dynamics in a sagebrush steppe in southeastern Idaho, USA. Vegetatio 78:151-155.

Avery, T. E., AND G. L. Berlin. 1992. Fundamentals of remote sensing and airphoto interpretation. Upper Saddle River, NJ, USA: Prentice Hall. 472 p.

Bates, J. D., R. F. Miller, and T. J. Svejcar. 2000. Understory dynamics in cut and uncut western juniper woodlands. Journal of Range Management 53:119-126.

BAtES, J. D., AND T. J. SVEJCAR. 2009 Herbaceous succession after burning cut western juniper trees. Western North American Naturalist 69:9-25.

BLAISDELL, J. P. 1953. Ecological effects of planned burning of sagebrush-grass range on the Upper Snake River Plains. Tech. Bull. 1975. Washington, DC, USA: US Department of Agriculture. $39 \mathrm{p}$.

Blaisdell, J. P., and W. F. Mueggler. 1956. Sprouting of bitterbrush (Purshia tridentata) following burning or top removal. Ecology 37:365-370.

Blaisdell, J. P., R. B. Murray, and E. D. McArthur. 1982. Managing Intermountain rangelands-sagebrush-grass ranges. Ogden, UT, USA: US Department of Agriculture, Forest Service, Intermountain Forest and Range Experiment Station. Gen. Tech. Rep. INT-134. 41 p.

Britton, C. M., G. R. McPherson, and F. A. Sneva. 1990. Effects of burning and clipping on five bunchgrasses in eastern Oregon. The Great Basin Naturalist 50:115-120.

Bunting, S. C. 1990. Prescribed fire effects in sagebrush-grasslands and pinyonjuniper woodlands. In: M. E. Alexander and G. F. Bisgrov [TECH. COORDS.]. The art and science of fire management: Proceedings of the 1 st Interior West Fire Council annual meeting and workshop. Edmonton, AB, Canada: Forestry Canada, Northwest Region, Northern Forestry Centre. Information Rep. NOR-X-309. p. 176-181. 
Bunting, S. C., B. M. Kilgore, AND C. L. Bushey. 1987. Guidelines for prescribed burning sagebrush-grass rangelands in the northern Great Basin. Ogden, UT, USA: USDA Forest Service, Intermountain Research Station. Gen. Tech. Rep. INT-231. 33 p.

Bunting, S. C., J. L. KingerY, and E. K. Strand. 1999. Effects of succession on species richness of the western juniper/sagebrush mosaic. Ecology and management of pinyon-juniper communities within the interior west. Ogden, UT, USA: USDA Forest Service GTR-RMRS-P-9. p. 76-81.

Bunting, S. C., R. RobBereCht, And G. E. Defosse. 1998. Length and timing of grazing on postburn productivity of two bunchgrasses in an Idaho experimental range. International Journal of Wildland Fire 8:15-20.

Bunting, S. C., E. K. Strand, And J. L. Kingery. 2007. Landscape characteristics of sagebrush-steppe/juniper woodland mosaics under various modeled prescribed fire regimes. In: R. E. Masters, and K. E. M. Galley [EDS.]. Proceedings 23rd Tall Timbers Fire Ecology Conference: Fire in grassland and shrubland ecosystems. Tallahassee, FL, USA. Tall Timbers Research Station. p. 50-57.

Burkhardt, J. W., and E. W. Tisdale. 1976. Cause of juniper invasion in southeastern Idaho. Ecology 57:472-484.

Chander, G., and B. L. Markham. 2003. Revised Landsat 5 TM radiometric calibration procedures, and postcalibration dynamic ranges. IEEE Transactions on Geoscience and Remote Sensing 41:2674-2677.

Cocke, A. E., P. Z. Fule, and J. E. CRouse. 2005. Comparison of burn severity assessments using differenced normalized burn ratio and ground data. International Journal of Wildland Fire 14:189-198.

Conrad, G. C., A. E. Jaramillo, K. Cormack, JR., and S. Rose. 1985. The role of the genus Ceanothus in western forest ecosystems. Portland, OR, USA: US Department of Agriculture, Forest Service, GTR-PNW-182. 72 p.

Diaz-Delgado, R., F. Lloret, and X. Pons. 2003. Influences of fire severity on plant regeneration through remote sensing imagery. International Journal of Remote Sensing 24:1751-1763.

Epting, J., D. VerbyLA, and B. Sorbel. 2005. Evaluation of remotely sensed indices for assessing burn severity in interior Alaska using Landsat TM and ETM+. Remote Sensing of Environment 96:328-339.

ESRI Software. 2010. ArcGIS Desktop v. 9.3, Redlands, CA, USA: Environmental Systems Research Inc.

French, N. H. F., E. S. Kasischke, R. J. Hall, K. A. Murphy, D. Verbyla, and E. E. Hoy. 2008. Using Landsat data to assess fire and burn severity in the North American boreal forest region: an overview and summary or results. International Journal of Wildland Fire 17:443-462.

Gamon, J. A., C. B. Field, M. L. Goulden, K. L. Griffin, A. E. Hartley, J. Greeske, J. Peñuelas, and R. Valentinl. 1995. Relationships between NDVI, canopy structure, and photosynthesis in three Californian vegetation types. Ecological Applications 5:28-41.

Gratkowski, H. J. 1962. Heat as a factor in germination of seeds of Ceanothus velutinus var. laevigatus T. \& G. [dissertation]. Corvallis, OR, USA: Oregon State University. $122 \mathrm{p}$.

Hardy, C. C., K. M. Schmidt, J. P. Menakis, and R. N. Sampson. 2001. Spatial data for national fire planning and fuel management. International Journal of Wildland Fire 10:353-372.

Harkness, A. L. 1998. Soil survey of Owyhee county area, Idaho. Washington, DC, USA: US Department of Agriculture, Natural Resource Conservation Service. 809 p.

Hoy, E. E., N. H. F. French, M. R. Turetsky, S. Trigg, and E. S. Kasischke. 2008. Evaluating the potential of Landsat TM/ETM+ imagery for assessing fire severity in Alaskan black spruce forests. International Journal of Wildland Fire 17:500514.

ITT VISUAL Information Solutions. 2010. ENVI software version 4.7. Boulder, CO, USA: ITT Visual Information Solutions.

Kasischke, E. S., M. R. Turetsky, R. D. Ottmar, N. H. F. French, E. E. Hoy, and E. S. Kane. 2008. Evaluation of the composite burn index for assessing fire severity in Alaskan black spruce forests. International Journal of Wildland Fire 17:515-526.

KeELEY, J. E. 2009. Fire intensity, fire severity and burn severity: a brief review of suggested uses. International Journal of Wildland Fire 18:116-126.

Key, C. H., AND N. C. Benson. 2006. Landscape assessment: ground measure of severity, the composite burn index; and remote sensing of severity, the normalized burn ratio. In D. C. Lutes, R. E. Keane, J. F. Caratti, C. H. Key, N. C. Benson, S. Sutherland, and L. J. Gangi [EDS.]. FIREMON: fire effects monitoring and inventory system. Ogden, UT, USA: US Department of Agriculture Forest Service, Rocky Mountain Research Station, Gen. Tech. Rep. RMRS-GTR-164CD: LA 1-51.

Lentile, L. B., Z. A. Holden, A. M. S. Smith, M. J. Falkowski, A. T. Hudak, P. Morgan, S. A. Lewis, P. E. Gessler, and N. C. Benson. 2006. Remote sensing techniques to assess active fire characteristics and post-fire effects. International Journal of Wildland Fire 15:319-345.

Lentile, L. B., A. M. S. Smith, A. T. Hudak, P. Morgan, M. J. Bobbit, S. A. Lewis, and P. R. RoBichaUd. 2009. Remote sensing for prediction of 1-year post-fire ecosystem condition. International Journal of Wildland Fire 18:594-608.

Lopez Garcia, M. J., and V. Caselles. 1991. Mapping burns and natural reforestation using thematic mapper data. Geocarto International 1:31-37.

McGarigal, K., AND B. J. Marks. 1995. FRAGSTATS: spatial pattern analysis program for quantifying landscape structure. Portland, OR, USA: US Department of Agriculture, Forest Service, Pacific Northwest Research Station General Technical Report PNW-351. 126 p.

McShane, M. C., and R. H. Sauer. 1985. Comparison of experimental fall burning and clipping on bluebunch wheatgrass. Northwest Science 59:313-318.

Miller, R. F., J. D. Bates, T. J. Svejcar, F. B. Pierson, and L. E. Eddleman. 2005. Biology, ecology, and management of western juniper. Corvallis, OR, USA: Oregon State University, Agricultural Experiment Station, Technical Bulletin 152. $82 \mathrm{p}$.

Mlller, J. D., ANd A. E. Thode. 2007. Quantifying burn severity in a heterogeneous landscape with a relative version of the delta normalized burn ratio (dNBR). Remote Sensing of Environment 109:66-80.

MlLleR, R. F., AND J. A. Rose. 1995. Historic expansion of Juniperus occidentalis in southeastern Oregon. Great Basin Naturalist 55:37-45.

NeuensChwander, L. F. 1980. Broadcast burning of sagebrush in the winter. Journal of Range Management 33:233-236.

Pierson, F. B., J. D. Bates, T. J. Svejcar, and S. Hardegree. 2007. Runoff and erosion after cutting western juniper. Range Ecology \& Management 60:285-292.

Quigley, T. M., R. W. Haynes, and R. T. Graham (tech eds.). 1996. An integrated scientific assessment for ecosystem management in the Interior Columbia River Basin and portions of the Klamath and Great Basins. Portland, OR, USA: US Department of Agriculture, Forest Service, Pacific Northwest Research Station General Technical Report PNW-GTR-382.

Range, P., P. Veisze, C. Beyer, and G. Zschaechner. 1982. Great Basin rate-of-spread study: fire behavior/fire effects. Reno, NV, USA: US Department of the Interior, Bureau of Land Management, Nevada State Office, Branch of Protection. $56 \mathrm{p}$.

Reinkensmeyer, D. P., R. F. Miller, R. G. Anthony, and V. E. Marr. 2007. Avian community structure along a mountain big sagebrush successional gradient. Journal of Wildlife Management 71:1057-1066.

RobBereCht, R., AND G. E. Defosse. 1995. The relative sensitivity of two bunchgrass species to fire. International Journal of Wildland Fire 5:127-134.

Rотн, A. D. 2004. Fire patterns within a successional gradient of a sagebrush steppe/ juniper woodland [thesis]. Moscow, ID, USA: University of Idaho. $114 \mathrm{p}$.

Roth, A. D., S. C. Bunting, and E. K. Strand. 2011. Relationships between landscape patterns and fire occurrence within a successional gradient in sagebrush steppe/ juniper woodland. International Journal of Wildland Fire 20:69-77.

Ruiz-Gallardo, J. R., S. Castaño, and A. Calera. 2004. Application of remote sensing and GIS to locate priority intervention areas after wildland fire in Mediterranean systems: a case study from south-eastern Spain. International Journal of Wildland Fire 13:241-252.

SAPSIS, D. B. 1990. Ecological effects of spring and fall prescribed burning on basin big sagebrush/ldaho fescue_bluebunch wheatgrass communities [thesis]. Corvallis, OR, USA: Oregon State University. $105 \mathrm{p}$.

Smith, A. M. S., L. B. Lentile, A. T. Hudak, and P. Morgan. 2007. Evaluation of linear spectral unmixing and dNBR for predicting post-fire recovery in a North American ponderosa pine forest. International Journal of Remote Sensing 28:5159-5166.

Smith, A. M. S., M. J. Wooster, N. A. Drake, F. M. Dipotso, M. J. Falkowski, and A. T. HudAK. 2005. Testing the potential of multi-spectral remote sensing for 
retrospectively estimating fire severity in African Savannahs. Remote Sensing of Environment 97:92-115.

Stebleton, A., And S. C. Bunting. 2009. Guides for qualifying fuels in the sagebrush steppe and juniper woodlands of the Great Basin. Denver, CO, USA: US Department of Interior, Bureau of Land Management, Technical Note 430, BLM/ ID/PT-09/002+2824. $81 \mathrm{p}$.

Strand, E. K., L. A. VierLing, and S. C. Bunting. 2009. Landscape composition in aspen woodlands under various modeled management scenarios. Ecological Modelling 220:175-191.

[USDA] US Department of Agriculture, Forest Service. 1996. Status of the interior Columbia basin: summary of scientific findings. Portland, OR, USA: Pacific Northwest Research Station, US Department of Agriculture, Forest Service, General Technical Report PNW-GTR-385. $151 \mathrm{p}$.

van Wagtendonk, J. W., R. R. Root, And C. Key. 2004. Comparison of AVIRIS and ETM+ detection capability for burn severity. Remote Sensing of Environment 92:397408.
Wang, J., P. M. Rich, K. P. Price, and W. D. Kettle. 2005. Relations between NDVI, grassland production, and crop yield in the central Great Plains. Geocarto International 20:5-11.

Western Regional Climate Center. 2003. Division of Atmospheric Sciences. Desert Research Institute, Reno, NV, USA. Available at: http://www.wrcc.dri.edu. Accessed 22 June 2010.

YanISH, C. R. 2002. Western juniper succession: changing fuels and fire behavior [thesis]. Moscow, ID, USA: University of Idaho. $96 \mathrm{p}$.

Young, R. P. 1983. Fire as a vegetation management tool in rangelands of the Intermountain Region. In: S. B. Monsen and N. Shaw [CompILERS]. Managing intermountain rangelands-improvement of range and wildlife habitats, Ogden, UT, USA: Intermountain Forest and Range Experiment Station, US Department of Agriculture, Forest Service, Gen. Tech. Rep. INT-157. p. 18-31.

Ziegenhagen, L. L., and R. F. Miller. 2009. Postfire recovery of two shrubs in the interiors of large burns in the intermountain west, USA. Western North American Naturalist 69:195-205. 